\title{
Pengelompokan Dokumen Menggunakan Dokumen Berlabel dan Tidak Berlabel Dengan Pendekatan Modified Heuristic Fuzzy Co-Clustering
}

\author{
Khadijah F. Hayati ${ }^{1}$, Resti Ludviani ${ }^{2}$, Arini R. Rosyadi ${ }^{3}$ \\ Program Studi Teknik Informatika, Institut Teknologi Sepuluh November \\ Jl. Sukolilo, Surabaya 60111, Jawa Timur \\ E-mail: ${ }^{1}$ dee.jafa@gmail.com, ${ }^{2}$ restiludvi@gmail.com, ${ }^{3}$ arini.rosyadi@gmail.com
}

Masuk: 12 Juni 2014; Direvisi: 30 Juni 2014; Diterima: 10 Juli 2014

\begin{abstract}
Document clustering is a method used to cluster the data of text documents in accordance with the categories of information held. However, a varyed number of text documents cause some problems in the process of document clustering. One of them is the result of hard clustering caused by unsupervised method. Thus proposed is a clustering using Modified Heuristic Fuzzy Co-clustering (HFCR) Algorithm with semi-supervised method that uses a document label as its learning process. The result of the experiments show that the proposed method achieves the best result when $T u=T v=0.01$, and it has precission value of 0.19 and recall value of 0.16. Modified Heuristic Fuzzy Co-clustering algorithm proposed gives more stable results compared to the results of standart HFCR method.
\end{abstract}

Keywords: Documents clustering, Fuzzy Co-clustering, Semi-supervised learning.

\begin{abstract}
Abstrak. Pengelompokan dokumen merupakan suatu metode yang digunakan untuk dapat mengelompokkan suatu data berupa dokumen teks sesuai dengan kategori dari informasi yang dimiliki. Akan tetapi dengan banyaknya dokumen teks yang bervariasi menyebabkan beberapa masalah timbul dari proses pengelompokan dokumen. Salah satu diantaranya adalah hasil pengelompokan yang bersifat hard clustering. Hal ini disebabkan karena proses pengelompokan yang diterapkan merupakan metode unsupervised. Berdasarkan hal tersebut maka diajukan suatu metode pengelompokan yang mengunakan Algoritma Heuristic Fuzzy Co-clustering dengan menerapkan metode semi-supervised yang menggunakan dokumen berlabel sebagai proses pembelajarannya. Hasil uji coba terhadap metode yang diusulkan menunjukkan Algoritma Heuristic Fuzzy Co-clustering usulan terbaik dicapai pada kondisi $T u=T v=d a n$ 0,01 dengan nilai precission 0,19 dan recall 0,16. Algoritma Modified Heuristic Fuzzy Co-clustering yang diusulkan memberikan hasil lebih stabil dibandingkan dengan hasil pengelompokan Algoritma Heuristic Fuzzy Co-clustering.

Kata Kunci: Pengelompokan dokumen, Fuzzy Co-clustering, Semi-supervised learning.
\end{abstract}

\section{Pendahuluan}

Perkembangan data meningkat dengan sangat signifikan dewasa ini. Jumlahnya meningkat dalam waktu yang singkat. Diantara data-data tersebut, data teks merupakan data yang banyak tersimpan (Cai, 2012). Akan tetapi, banyaknya data teks yang tersimpan mempersulit pengguna untuk dapat mendapatkan informasi yang sesuai dengan topik yang diinginkan. Oleh karena itu, pengguna membutuhkan suatu proses filtering untuk dapat mendapatkan informasi yang tepat.

Metode pengelompokan dokumen merupakan metode yang tepat untuk dapat melakukan pengelompokan suatu data dokumen teks yang besar, sehingga menjadi kelompokkelompok kecil yang sesuai dengan kategori dari informasi yang terdapat dalam data teks (Yan, 2013). Pada prosesnya, pengelompokan dokumen merupakan teknik unsupervised yang tidak menggunakan data latih, yaitu berupa dokumen berlabel, untuk mendapatkan learning model (Yan, 2013) dan (Liu, 2013). Hal tersebut menyebabkan hasil yang didapatkan dari proses pengelompokan menjadi tidak optimal. Selain itu, kendala dalam dokumen teks adalah dapat ditemukannya lebih dari satu topik dalam satu dokumen, hal ini menyebabkan terjadinya hard clustering. 
Penerapan metode semi-supervised pada proses pengelompokan dokumen dapat mengoptimalkan hasil pengelompokan menjadi lebih efektif. Karena metode semi-supervised melibatkan beberapa dokumen yang telah berlabel untuk digunakan dalam proses pengelompokan (Yan, 2013) dan (Liu, 2013).

Penelitian ini menerapkan Algoritma Heuristic Fuzzy Co-clustering, selain menggunakan metode semi-supervised. Algoritma Heuristic Fuzzy Co-clustering merupakan suatu algoritma yang cukup efektif untuk melakukan proses pengelompokan terhadap dokumen. Algoritma Heuristic Fuzzy Co-clustering digunakan pada banyak data yang bi-partisi, misalnya data bi-partisi berdasarkan gambar spektral dan juga dokumen teks yaitu frekuensi kata yang terdapat dalam suatu dokumen (Yan, 2013). Disamping itu, Algoritma Heuristic Fuzzy Coclustering memiliki kelebihan untuk dapat menghasilkan group yang tidak bersifat hard cluster, yaitu anggota group yang satu dapat menjadi bagian dari group yang lain (Tjhi, 2008). Adapun tujuan dari penelitian ini adalah untuk melakukan perbandingan antara algoritma yang telah ada HFCR dengan modifikasi algoritma yang diajukan, HFCR dengan menerapkan metode semisupervised pada proses pengelompokan dokumen.

Dalam penulisan hasil penelitian ini, dijabarkan menjadi beberapa bagian. Pada sub-bab kedua, diberikan beberapa penelitian terkait. Selanjutnya pada sub-bab ketiga diberikan penjelasan terkait dengan metode yang akan diusulkan dalam penelitian ini. Dan pada sub-bab keempat dan kelima diberikan skenario dan hasil pengujian dari sistem yang dibuat dan juga analisa dari hasil pengujian. Dan terakhir pada sub-bab keenam dipaparkan kesimpulan dari apa yang telah dilakukan dalam penelitian.

\section{Tinjauan Pustaka}

Dalam penelitian yang telah dilakukan sebelumnya (Tjhi, 2008), penelitian dilakukan untuk dapat memberikan jalan keluar terhadap permasalahan yang timbul dalam penerapan Algoritma Fuzzy Clustering for Categorical Multivariate Data (FCCM) dan Fuzzy CoClustering of Document and Keyword (Fuzzy Codok), yang menerapkan pendekatan partitioning-ranking. Permasalahan pertama adalah akurasi dalam proses pengelompokan. Hal ini disebabkan adanya tumpang tindih antara feature yang dilakukan perangkingan. Permasalahan kedua adalah pemrosesan antara object dan feature yang dilakukan secara berbeda.

Berdasarkan permasalahan tersebut, penelitian tersebut mengajukan suatu algoritma yang disebut dengan Heuristic Fuzzy Co-clustering with the Ruspini's condition (HFCR) yang menerapkan pendekatan dual-partitioning. Algoritma ini diajukan untuk dapat memberikan solusi pada kedua permasalahan, yaitu dengan menerapkan pendekatan partisi untuk digunakan pada object dan juga membership feature. Dengan demikian maka akurasi dari hasil pengelompokan menjadi lebih alami. Selain itu, algoritma HFCR diketahui merupakan algoritma yang mampu menangani noise yang terdapat dalam suatu dokumen.

Penelitian (Yan, 2013) merupakan penelitian lanjutan dari (Tjhi, 2008) yang memaparkan beberapa permasalahan yang terjadi pada pengelompokan dokumen antara lain ukuran dataset teks yang besar, noise, overlapping, dan ukuran dimensi yang tinggi. Berdasarkan hal tersebut, beberapa teknik dikembangkan seperti (a) Co-clustering yang efektif dalam menangani data dengan dimensi tinggi. (b) Fuzzy clustering yang merepresentasikan overlapping cluster. (c) Model-based clustering yang mampu menangani data outlier, tetapi memiliki kompleksitas tinggi. Di lain pihak, pengelompokan merupakan metode unsupervised learning yang masih sulit untuk menyelesaikan dataset yang kompleks. Untuk itu, diperlukan adanya penerapan pendekatan semi-supervised.

Penelitian ini mengusulkan metode dokumen pengelompokan yang mengkombinasikan kekuatan dari Teknik Fuzzy Co-clustering (Tjhi, 2008), dan metode semi-supervised yang disebut dengan Heuristic Semi-Supervised Fuzzy Co-Clustering Algorithm (SS-HFCR). Pengembangan metode ini bertujuan untuk meningkatkan akurasi pengelompokan, mengurangi sensitivitas terhadap parameter fuzzy dengan pengetahuan terbatas, serta menjaga kompleksitas algoritma relatif rendah. 
Prinsip dasar semi-supervised dalam penelitian ini adalah memanfaatkan pengetahuan yang terbatas dalam bentuk kendala berpasangan (pair-wise constraint) pada dokumen. Batasan ditentukan dari dua dokumen dengan mempertimbangkan similaritas satu sama lain.

Pengujian dilakukan pada kasus toy problem dan beberapa dataset besar dengan kriteria evaluasi berdasarkan akurasi, stabilitas, dan efisiensi. Pada pengujian akurasi, SS-HFCR dibandingkan dengan PMFCC, SS-HFCR menghasilkan akurasi yang lebih baik untuk semua dataset. Pada pengujian stabilitas, SS-HFCR menunjukkan hasil yang lebih baik dari PMFCC pada jumlah constraint yang terus meningkat. Pada pengujian efisiensi waktu, SS-HFCR memiliki iterasi proses paling sedikit dibandingkan metode lainnya (SS-WNMF, Sd-Kmeans, SFCM) dengan kompleksitas algoritma yang setara dengan Sd-Kmeans \& SFCM.

Di lain pihak, penelitian (Liu, 2013) mengemukakan bahwa metode pengelompokan yang banyak digunakan adalah metode yang bertipe diskriminatif atau generatif. Dalam proses pengelompokan ini, sering kali menghasilkan group yang bersifat hard cluster.

Pada penelitian ini, penulis menerapkan metode semi-unsupervised untuk melakukan proses pengelompokan dokumen, yaitu dengan menggunakan dokumen berlabel dan juga tidak berlabel, sehingga hasil pengelompokan yang didapatkan bersifat soft cluster.

Metode yang diajukan dalam penelitian ini adalah mengadopsi teknik dari metode pengelompokan dalam tipe diskriminatif dan juga generatif. Pada jenis diskriminatif, metode ini menggunakan teknik $K$-Means yang bertujuan untuk meminimalisir nilai jarak rata-rata antar object dan juga centroid dari tiap-tiap group. Dalam mengadaptasi jenis generatif, metode ini bertujuan untuk dapat menggabungkan fungsi membership, sehingga pada tiap satu object dapat menjadi bagian dari beberapa kelompok.

Pada penelitian ini dihasilkan bahwa dengan menggunakan Algoritma Fuzzy Semi KMeans ini, dapat menghasilkan group yang optimal. Walaupun terdapat beberapa batasanbatasan yang kurang jelas.

\section{Metode yang diusulkan}

Dari penelitian yang telah dianalisa pada sub-bab sebelumnya, maka dalam penelitian ini akan mengajukan suatu proses pengelompokan dokumen dengan menggunakan Algoritma Heuristic Fuzzy Co-clustering dengan menerapkan metode semi-supervised.

Dalam penelitian ini dilakukan kombinasi dari dua penelitian yang telah dilakukan. Penggunaan Algoritma Heuristic Fuzzy Co-clustering didasarkan pada penelitian (Tjhi, 2008) dan penerapan metode semi-supervised dilandaskan pada penelitian(Liu, 2013). Berbeda dengan pendekatan semi-supervised SS-HFCR yang menggunakan pair-wise constraint (Yan, 2013), metode yang diusulkan menerapkan semi-supervised dengan menggunakan dokumen berlabel dan tidak berlabel (Liu, 2013).

Usulan dari penelitian ini dijabarkan pada Gambar 1. Pada Alur metode digambarkan, diberikan suatu masukan yaitu suatu data berupa dokumen teks. Dokumen teks digunakan sebagai masukanan merupakan data yang didapatkan dari 20NewsGroup. Selanjutnya dokumen masukkan dilakukan proses pre-proses untuk mendapatkan term-term yang akan digunakan dalam proses pengelompokan dokumen(Chen, 2010).

Pada Gambar 1, proses pengelompokan digambarkan dalam suatu kotak yang berisikan beberapa proses. Termasuk didalamnya merupakan proses dari penerapan metode semisupervised. Proses pengelompokan akan diawali dengan melakukan pre-proses terhadap dokumen masukan dengan melewati beberapa tahapan pre-proses pada dokumen teks (Gambar 2). Pada tahap pre-proses, dilakukan ekstraksi term dari masukan dokumen. Term yang tidak memberikan makna terhadap dokumen, yaitu term yang termasuk stopword dihapus. Proses selanjutnya adalah menyeleksi term-term yang telah didapatkan pada pre-proses. Penyeleksian term-term, sebelumnya dilakukan pembobotan term-term tersebut dengan menggunakan Algoritma tf-idf. Pada proses ini term-term yang diseleksi tidak lagi berupa kata akan tetapi berupa suatu nilai bobot dari kata tersebut (Chen, 2010) dalam bentuk vector bobot dokumen. 


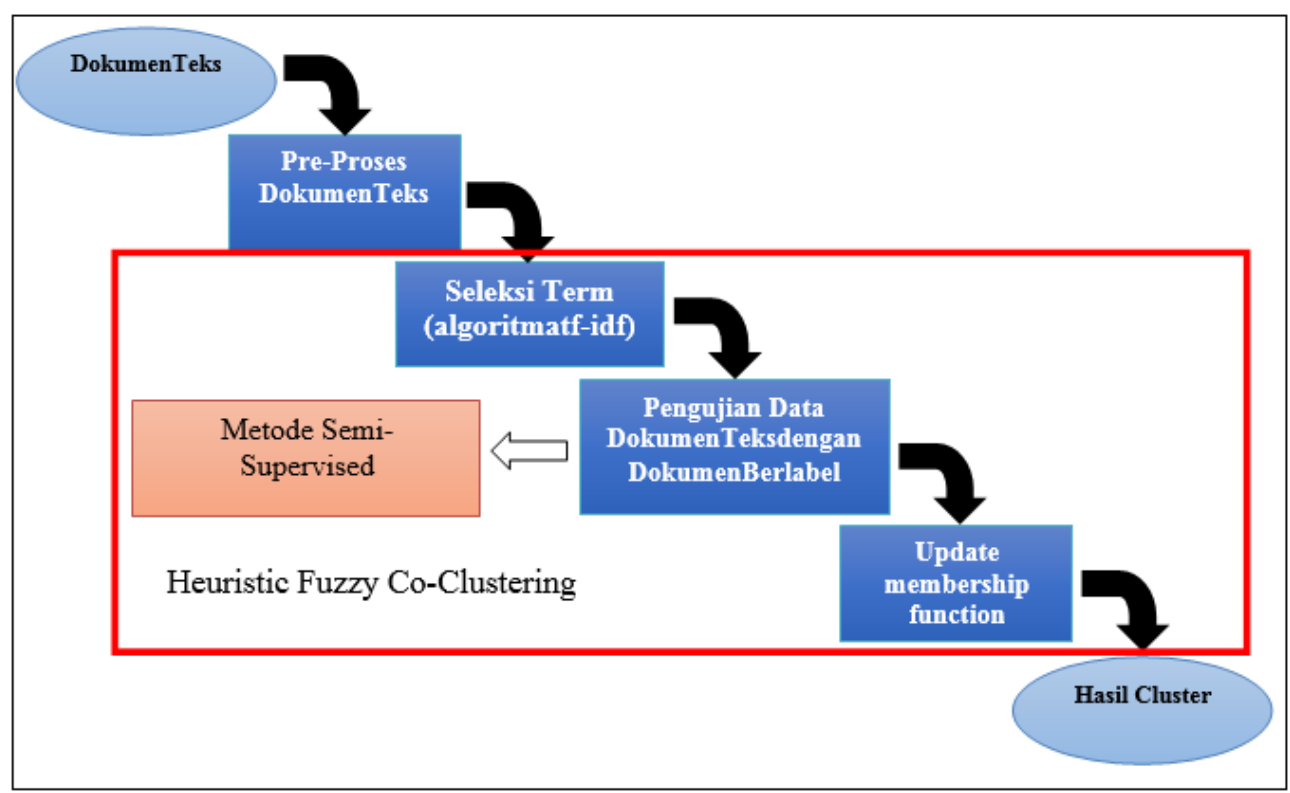

Gambar 1. Alur metode yang diajukan

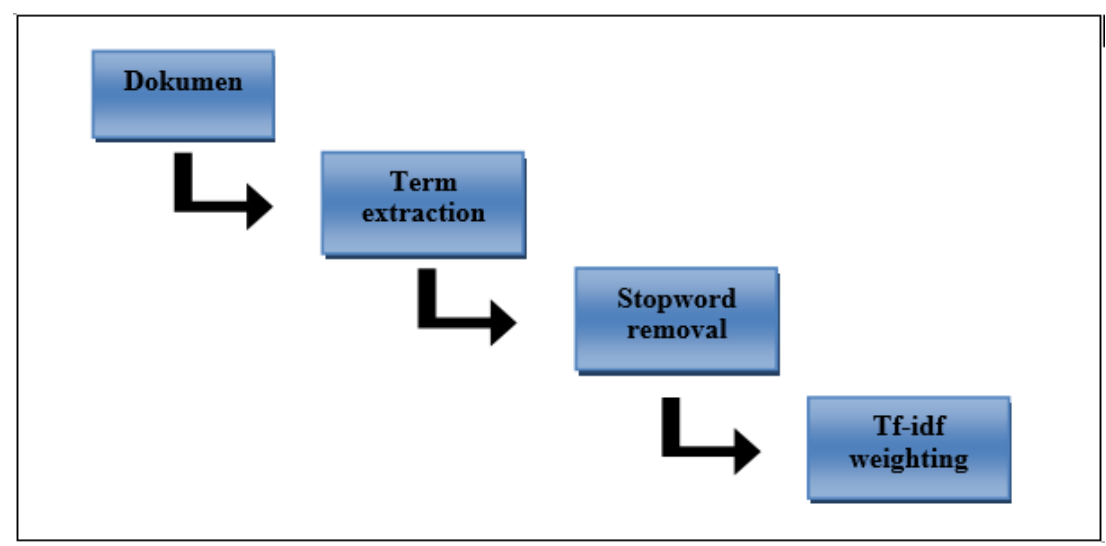

Gambar 2. Pre-proses pada dokumen teks

Pada tahap selanjutnya merupakan metode semi-supervised. Tahapan ini dilakukan dengan melakukan pengujian terhadap dokumen masukan dengan dokumen berlabel yang telah tersimpan. Pengujian dilakukan untuk mencocokkan kedua dokumen tersebut. Dokumen masukan yang dianggap sama dengan dokumen berlabel akan dikelompokkan pada kluster yang sesuai dengan dokumen berlabel. Proses pencocokan ini merupakan suatu langkah untuk menciptakan learning model.

Setelah tahapan pengujian dokumen masukan dengan dokumen berlabel, proses dilanjutkan dengan melakukan perubahan terhadap nilai membership pada formula (1) dan juga nilai objek pada formula (2). Proses perubahan terhadap nilai tersebut, dilakukan berdasarkan dari hasil proses sebelumnya. Perubahan akan dilakukan jika dokumen masukan tidak termasuk dalam dokumen berlabel.

Berdasarkan penelitian Tjhi, rumus perubahan derajat keanggotaan objek dan fitur ditunjukkan pada persamaan (1) dan (2).

$$
u_{c i}=\frac{\left\{\frac{\sum_{j=1}^{K} v_{c j} d_{i j}}{T_{u} \sum_{j=1}^{K} v_{c j}}\right\}}{\sum_{f=1}^{C}\left\{\frac{\sum_{j=1}^{K} v_{f j} d_{i j}}{T_{u} \sum_{j=1}^{K} v_{f j}}\right\}}
$$




$$
v_{c j}=\frac{\left\{\frac{\sum_{i=1}^{N} u_{c i} d_{i j}}{T_{v} \sum_{i=1}^{N} u_{c i}}\right\}}{\sum_{f=1}^{C}\left\{\frac{\sum_{i=1}^{N} u_{f i} d_{i j}}{T_{v} \sum_{i=1}^{N} u_{f i}}\right\}}
$$

Keterangan:

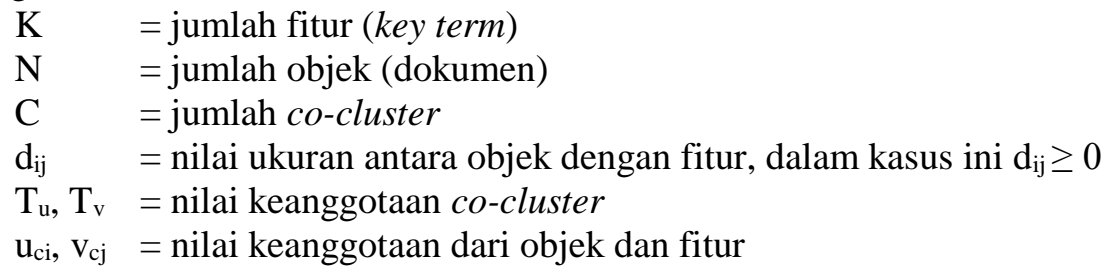

Proses diatas berulang sesuai dengan jumlah dokumen masukan atau akan terhenti jika telah mendekati nilai error rate yang telah ditentukan pada awal proses berjalan. Pseudo-code HFCR (Tjhi, 2008) ditunjukkan Kode 1, sedangkan pseudo-code dari metode yang diusulkan diberikan pada Kode 2.

\section{Kode 1. Algoritma Heuristic Fuzzy Co-clustering (HFCR)}

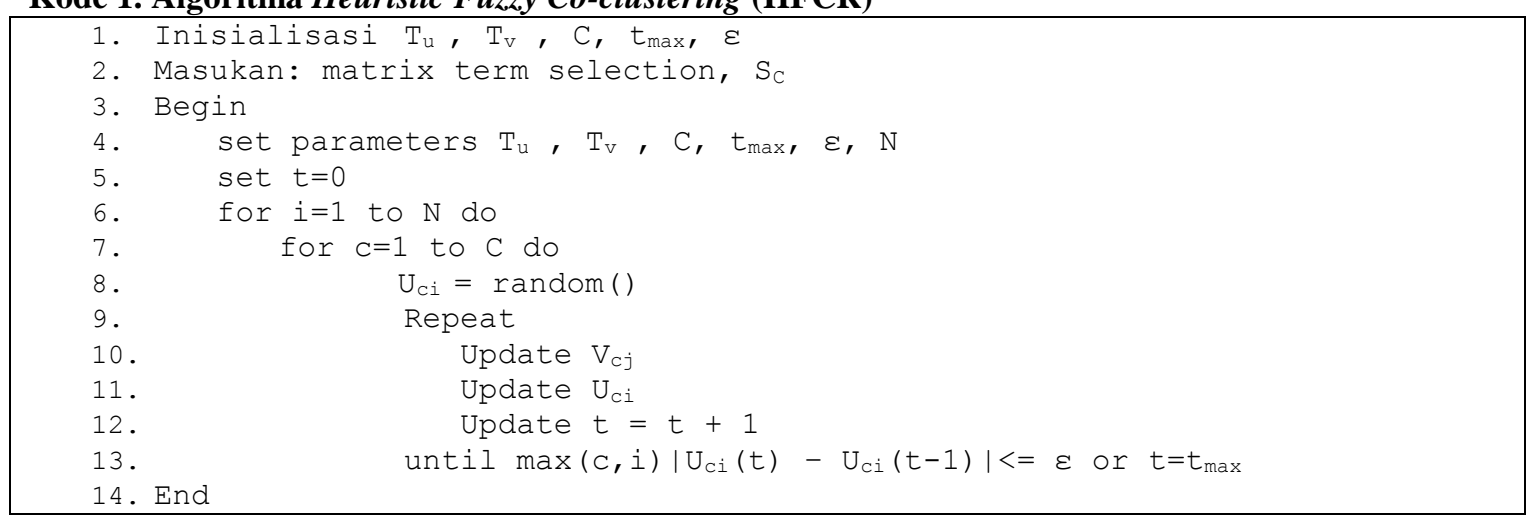

Kode 2. Modifikasi Algoritma Heuristic Fuzzy Co-clustering (HFCR) yang diusulkan

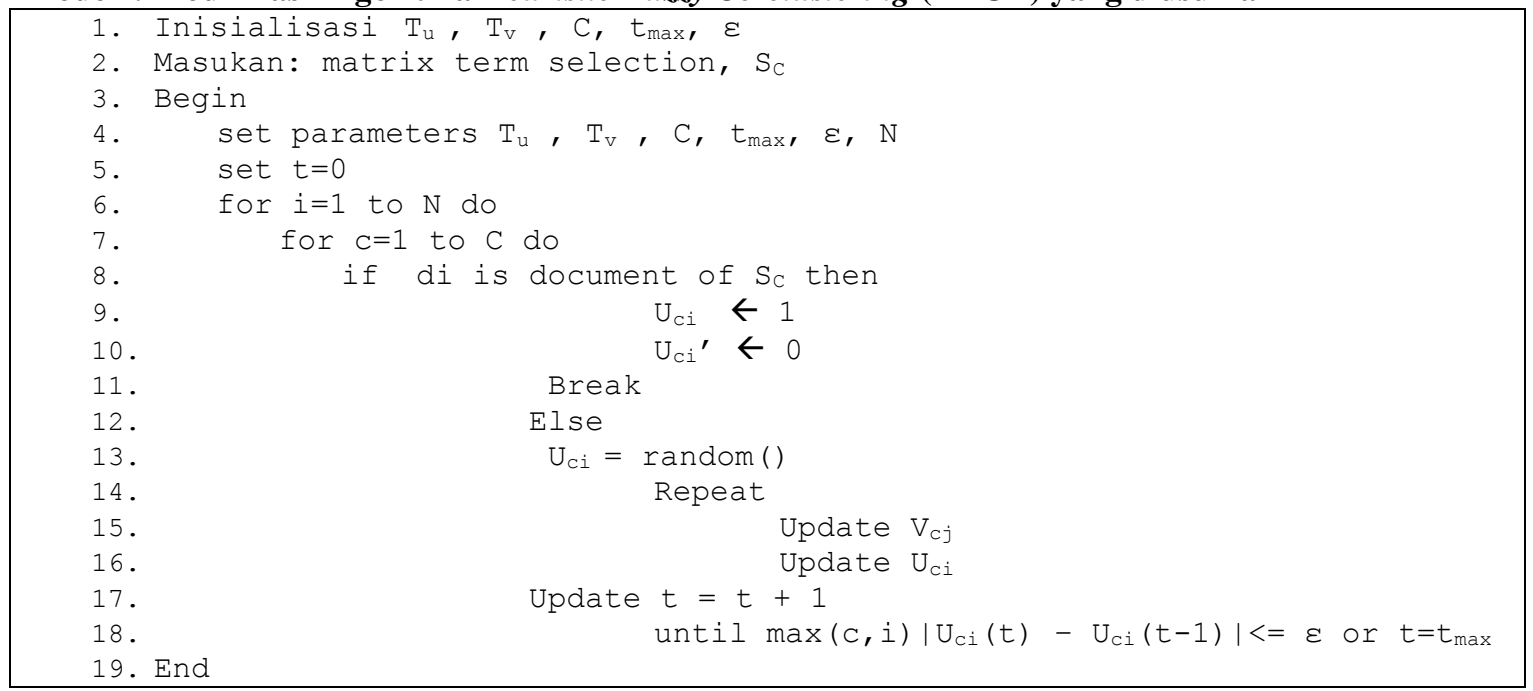




\section{Skenario dan Hasil Pengujian \\ 4.1 Skenario Pengujian}

Pada tahap ini, pengujian terhadap metode yang diajukan dilakukan dengan menggunakan dataset sebanyak 600 dokumen teks yang didapatkan dari situs penyedia dataset dokumen teks, yaitu 20NewsGroup. Dokumen-dokumen tersebut merupakan dokumen berita yang tidak berlabel yang termasuk dalam beberapa kategori yang berbeda. Pada pengujian ini dokumen berlabel digunakan dalam penggujian metode semi-supservised menggunakan data training sebanyak 200 dokumen berlabel yang didapatkan dari 20NewsGroup. Dokumen berlabel tersebut diambil secara acak dari 6 kategori berita dalam 20NewsGroup. Dokumen berlabel berperan sebagai pembanding terhadap dokumen dataset yang dikelompokkan.

Pengujian dilakukan untuk membandingkan hasil dari pengelompokan dokumen dari 2 metode, yaitu metode HFCR dan HFCR yang diusulkan. Dokumen masukan sejumlah 600 dokumen dikelompokkan kedalam enam kluster menggunakan metode HFCR dan HFCR yang diusulkan. Pengujian terhadap masing-masing metode dilakukan sebanyak empat kali pengujian dengan variasi inisialisasi nilai variabel berturut-turut adalah $\mathrm{Tv}=\mathrm{Tu}=0,001, \mathrm{~T} v=\mathrm{Tu}=0,01$, $\mathrm{Tv}=\mathrm{Tu}=0,1$, dan $\mathrm{Tv}=\mathrm{Tu}=1$. Hasil uji coba tersebut dievaluasi menggunakan perhitungan recall dan precision pada persamaan 3 dan 4 .

$$
\begin{aligned}
& \text { Precision }=\frac{T P}{T P+F P} \\
& \text { Recall }=\frac{T P}{T P+T N}
\end{aligned}
$$

Sebagaimana yang ditunjukkan pada tabel 1, TP (true positif) merupakan jumlah dokumen yang dikelompokkan secara tepat oleh system. FP (false positif) merupakan jumlah dokumen yang berada pada kelompok dokumen yang tidak tepat. TN (true negatif) merupakan jumlah dokumen yang tidak ter-retrieve. Berdasarkan evaluasi menggunakan precission, maka efektivitas dari metode yang digunakan dapat diketahui. Evaluasi dengan recall akan menunjukkan kemampuan metode dalam mengelompokkan dokumen dengan tepat.

Tabel 1. Recall dan Precision

\begin{tabular}{cccc}
\hline & & \multicolumn{2}{c}{ Clustering secara Manual } \\
\cline { 2 - 4 } & $\begin{array}{c}\text { Dokumen yang } \\
\text { Relevan }\end{array}$ & $\begin{array}{c}\text { Dokumen yang } \\
\text { Tidak Relevan }\end{array}$ \\
\hline \multirow{2}{*}{$\begin{array}{c}\text { Clustering menggunakan } \\
\text { modifikasi algoritma }\end{array}$} & $\begin{array}{c}\text { Dokumen yang } \\
\text { Ditemukan }\end{array}$ & True Positive & False Posotive \\
\cline { 2 - 4 } & $\begin{array}{c}\text { Dokumen yang } \\
\text { Tidak Ditemukan }\end{array}$ & True Negative & False Negative \\
\hline
\end{tabular}

\subsection{Hasil Pengujian}

Hasil pengujian dan perbandingan terhadap Algoritma Heuristic Fuzzy Co-clustering dengan Algoritma Heuristic Fuzzy Co-clustering usulan ditunjukkan pada Tabel 2 sampai Tabel 5 berikut ini. Pengujian dilakukan dengan variasi inisialisasi nilai variabel berturut-turut (a) $\mathrm{Tv}=\mathrm{Tu}=0,001$. (b) $\mathrm{Tv}=\mathrm{Tu}=0,01$. (c) $\mathrm{Tv}=\mathrm{Tu}=0,1$. (d) $\mathrm{Tv}=\mathrm{Tu}=1$ terhadap masing-masing metode. Variasi inisialisasi variabel Tv dan Tu tersebut menjadi kriteria pengukuran recall dan precision pada penelitian ini. Variabel Tv dan Tu yang digunakan pada penelitian ini merupakan nilai keanggotaan co-clustering yang digunakan pada perhitungan nilai membership (Uci) dengan formula 1 dan nilai objek (Vcj) dengan formula 2. Dengan demikian, perbedaan nilai $\mathrm{Tv}$ dan $\mathrm{Tu}$ diasumsikan akan mempengaruhi hasil dari pengelompokan dokumen. Hal ini dibuktikan dari hasil uji coba yang telah dilakukan.

Pada Tabel 2 diberikan hasil perhitungan Precision pada masing-masing hasil pengelompokan beserta dengan nilai rata-rata dari Algoritma Heuristic Fuzzy Co-clustering. Dan Tabel 3 adalah nilai dari precision dari Algoritma Heuristic Fuzzy Co-clustering yang 
diusulkan. Tabel 4 dan Tabel 5 merupakan hasil perhitungan recall dari Algoritma Heuristic Fuzzy Co-clustering dan Algoritma Heuristic Fuzzy Co-clustering yang diusulkan.

Tabel 2. Nilai Precision Algoritma Heuristic Fuzzy Co-clustering

\begin{tabular}{crrrr}
\hline & \multicolumn{5}{c}{ HFCR } \\
\hline \multirow{2}{*}{ Cluster } & \multicolumn{5}{c}{ Nilai Tv Tu } \\
\cline { 2 - 5 } & $\mathbf{0 , 0 0 1}$ & $\mathbf{0 , 0 1}$ & $\mathbf{0 , 1}$ & $\mathbf{1}$ \\
\hline 1 & 0,26 & 0,65 & 0,39 & 0,31 \\
\hline 2 & 0,17 & 0,17 & 0,24 & 0 \\
\hline 3 & 0,16 & 0,08 & 0,17 & 0,12 \\
\hline 4 & 0 & 0 & 0 & 0,01 \\
\hline 5 & 0 & 0,42 & 0,03 & 0,06 \\
\hline 6 & 0,06 & 0,04 & 0,16 & 0 \\
\hline Rata-rata & $\mathbf{0 , 1 1}$ & $\mathbf{0 , 2 3}$ & $\mathbf{0 , 1 7}$ & $\mathbf{0 , 0 8}$ \\
\hline
\end{tabular}

Tabel 3. Nilai Precision Algoritma Heuristic Fuzzy Co-clustering Usulan

\begin{tabular}{crrrr}
\hline & \multicolumn{5}{c}{ HFCR USULAN } \\
\hline \multirow{2}{*}{ Cluster } & \multicolumn{5}{c}{ Nilai Tv Tu } \\
\cline { 2 - 6 } & $\mathbf{0 , 0 0 1}$ & $\mathbf{0 , 0 1}$ & $\mathbf{0 , 1}$ & $\mathbf{1}$ \\
\hline $\mathbf{1}$ & 0,28 & 0,54 & 0,48 & 0,5 \\
\hline $\mathbf{2}$ & 0,38 & 0,08 & 0,04 & 0 \\
\hline $\mathbf{3}$ & 0,12 & 0,21 & 0,05 & 0,22 \\
\hline $\mathbf{4}$ & 0 & 0 & 0 & 0 \\
\hline $\mathbf{5}$ & 0,13 & 0,25 & 0,36 & 0,2 \\
\hline $\mathbf{6}$ & 0,17 & 0,05 & 0 & 0,04 \\
\hline rata-rata & $\mathbf{0 , 1 7}$ & $\mathbf{0 , 1 9}$ & $\mathbf{0 , 1 5}$ & $\mathbf{0 , 1 6}$ \\
\hline
\end{tabular}

Tabel 4. Nilai Recall Algoritma Heuristic Fuzzy Co-clustering

\begin{tabular}{crrrr}
\hline & \multicolumn{5}{c}{ HFCR } \\
\hline \multirow{2}{*}{ Cluster } & \multicolumn{5}{c}{ Nilau Tv Tu } \\
\cline { 2 - 5 } & $\mathbf{0 , 0 0 1}$ & $\mathbf{0 , 0 1}$ & $\mathbf{0 , 1}$ & $\mathbf{1}$ \\
\hline 1 & 0,10 & 0,07 & 0,36 & 0,06 \\
\hline 2 & 0,22 & 0,06 & 0,09 & 0 \\
\hline 3 & 0,06 & 0,01 & 0,10 & 0,08 \\
\hline 4 & 0 & 0 & 0 & 1 \\
\hline 5 & 0 & 0,43 & 0,05 & 0,26 \\
\hline 6 & 0,30 & 0,47 & 0,45 & 0 \\
\hline Rata-rata & $\mathbf{0 , 1 1}$ & $\mathbf{0 , 1 7}$ & $\mathbf{0 , 1 7}$ & $\mathbf{0 , 2 3}$ \\
\hline
\end{tabular}

Tabel 5. Nilai Recall Algoritma Heuristic Fuzzy Co-clustering Usulan

\begin{tabular}{crrrr}
\hline \multicolumn{5}{c}{ HFCR USULAN } \\
\hline \multirow{2}{*}{ Cluster } & \multicolumn{5}{c}{ Nilai Tv Tu } \\
\cline { 2 - 5 } & $\mathbf{0 , 0 0 1}$ & $\mathbf{0 , 0 1}$ & $\mathbf{0 , 1}$ & $\mathbf{1}$ \\
\hline $\mathbf{1}$ & 0,03 & 0,18 & 0,08 & 0,01 \\
\hline $\mathbf{2}$ & 0,08 & 0,06 & 0,01 & 0 \\
\hline $\mathbf{3}$ & 0,06 & 0,57 & 0,01 & 0,08 \\
\hline $\mathbf{4}$ & 0 & 0 & 0 & 0 \\
\hline $\mathbf{5}$ & 0,10 & 0,05 & 0,68 & 0,14 \\
\hline $\mathbf{6}$ & 0,23 & 0,1 & 0 & 0,63 \\
\hline rata-rata & $\mathbf{0 , 0 8}$ & $\mathbf{0 , 1 6}$ & $\mathbf{0 , 1 3}$ & $\mathbf{0 , 1 4}$ \\
\hline
\end{tabular}

\section{Diskusi}

Pada Gambar 3, nilai precission terbaik pada Algoritma Heuristic Fuzzy Co-clustering usulan dicapai pada kondisi $\mathrm{Tu}=\mathrm{Tv}=0,01$ dengan nilai 0,19. Demikian pula pada Algoritma Heuristic Fuzzy Co-clustering $\mathrm{R}$, nilai precission terbaik terjadi pada kondisi $\mathrm{Tu}=\mathrm{Tv}=0,01$ dengan nilai 0,26 . Dari perbandingan rata-rata precission antara kedua metode tersebut (gambar 5), tampak bahwa HFCR usulan memiliki nilai precission yang lebih tinggi dibandingkan metode HFCR pada kondisi $\mathrm{Tu}=\mathrm{Tv}=0,001$ dan 1 . Sedangkan pada kondisi $\mathrm{Tu}=\mathrm{Tv}=0,01$ dan 0,1 , metode HFCR memiliki nilai precission lebih tinggi dibandingkan metode usulan. Precission pada tiap enam kluster hasil pengujian menunjukkan bahwa data kluster pertama memiliki nilai precission yang lebih tinggi dibandingkan kelima kluster lainnya baik pada metode HFCR usulan maupun HFCR, kecuali pada kodisi $\mathrm{Tu}=\mathrm{Tv}=0,001$ dengan metode HFCR usulan. 


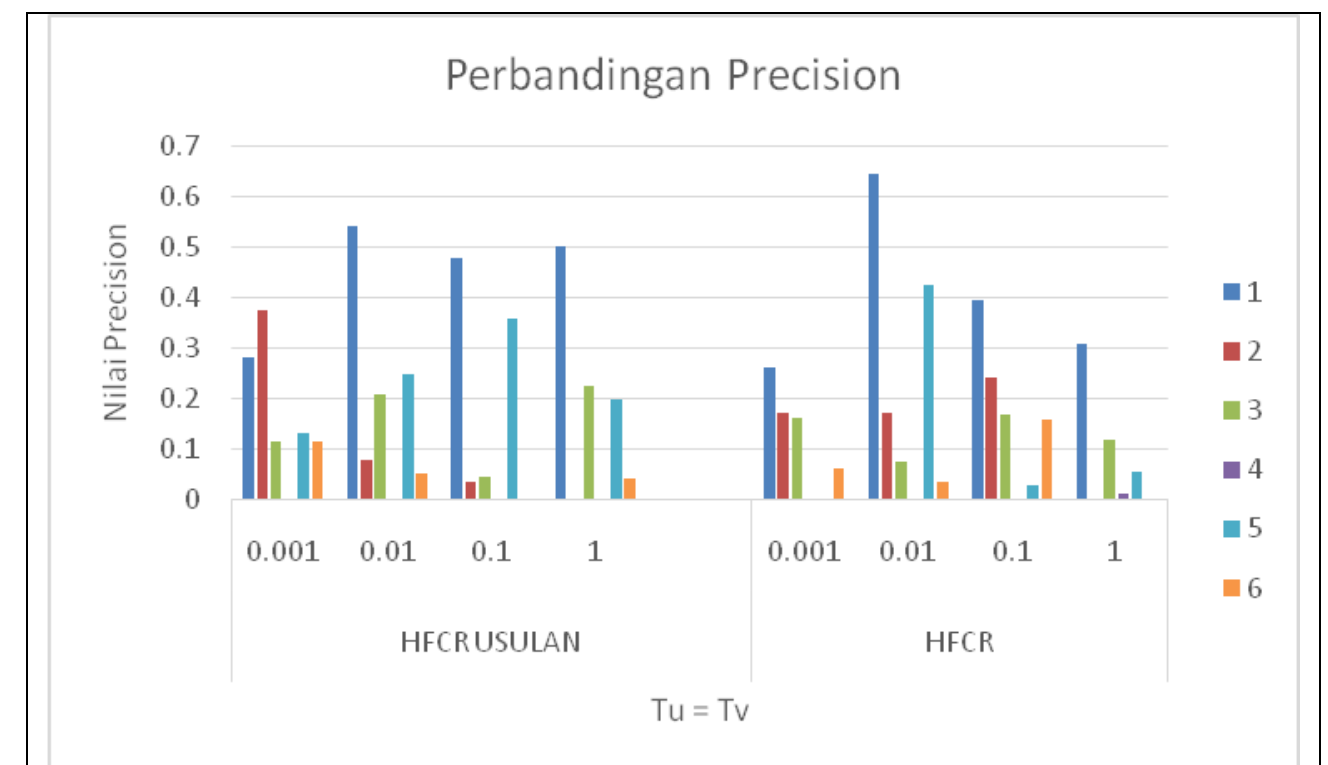

Gambar 3. Perbandingan Nilai Precision Algoritma Heuristic Fuzzy Co-clustering dengan Algoritma Heuristic Fuzzy Co-clustering usulan

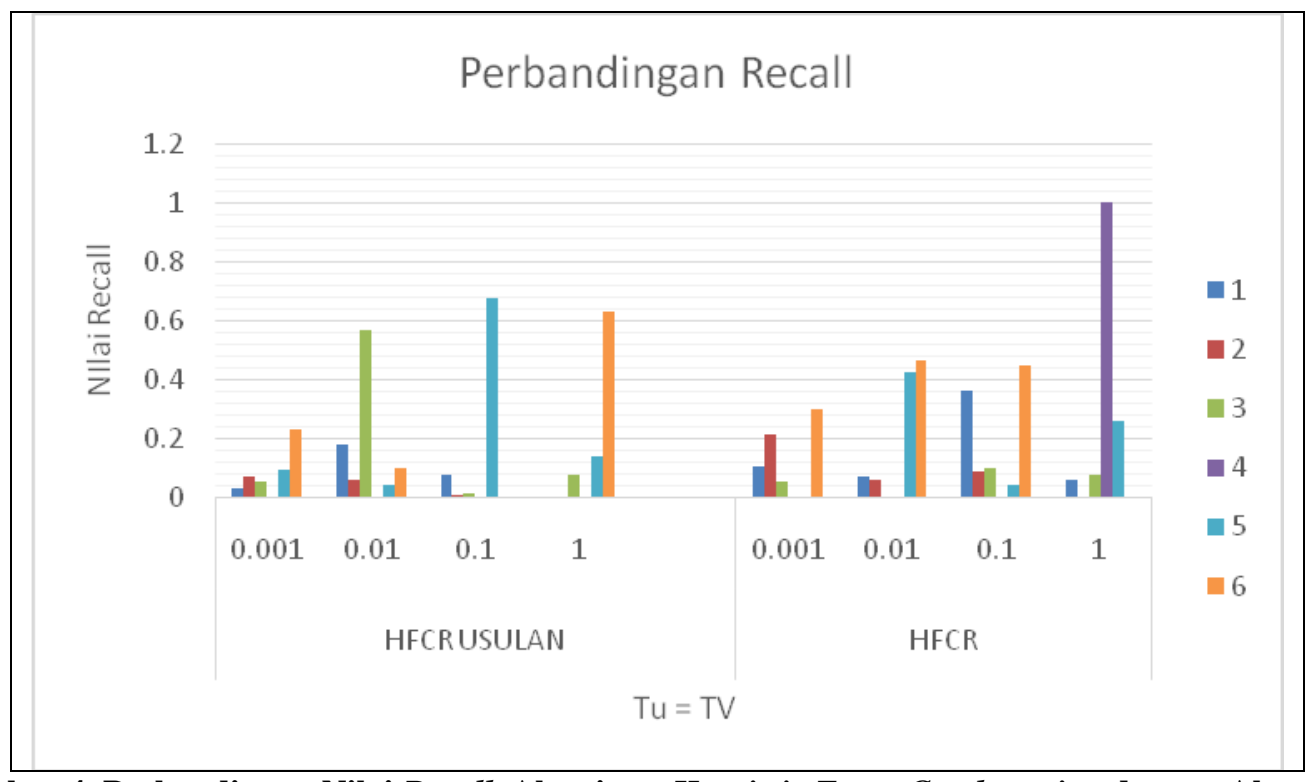

Gambar 4. Perbandingan Nilai Recall Algoritma Heuristic Fuzzy Co-clustering dengan Algoritma Heuristic Fuzzy Co-clustering usulan 


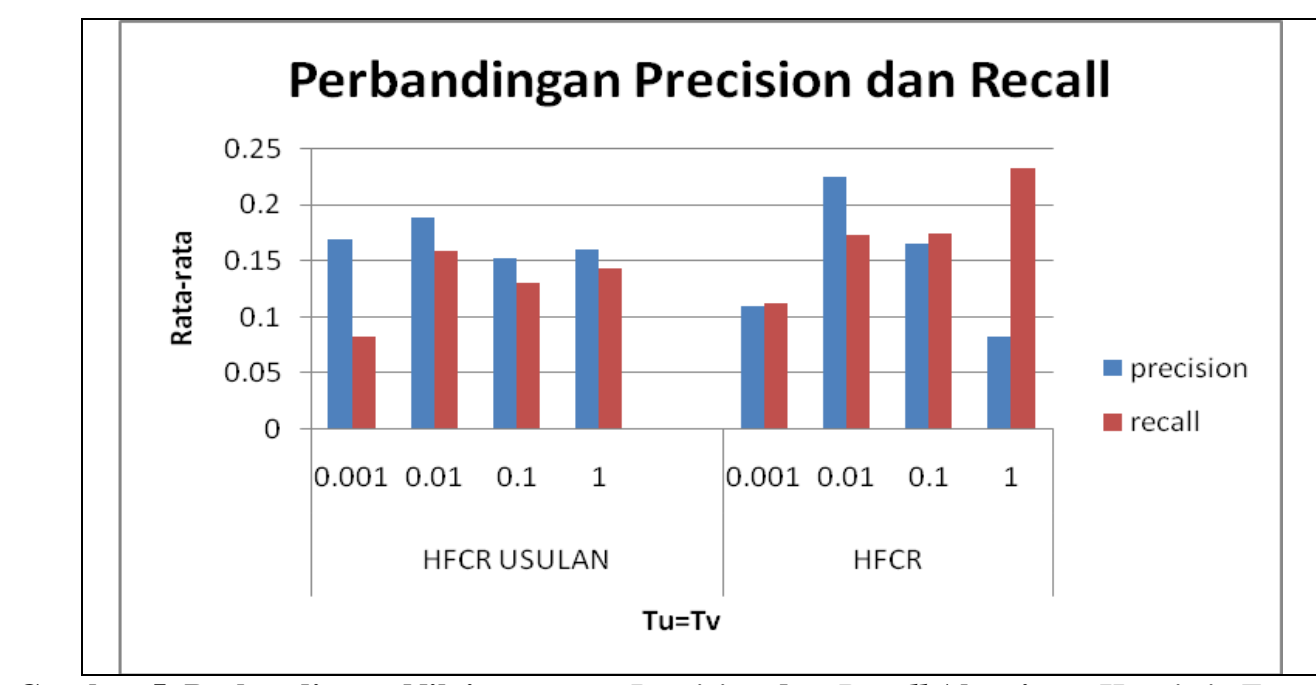

Gambar 5. Perbandingan Nilai rata-rata Precision dan Recall Algoritma Heuristic Fuzzy Coclustering dengan Algoritma Heuristic Fuzzy Co-clustering usulan

Pada Gambar 4, nilai recall terbaik pada Algoritma Heuristic Fuzzy Co-clustering usulan dicapai pada kondisi $\mathrm{Tu}=\mathrm{Tv}=0,01$ dengan nilai sebesar 0,16. Sedangkan pada Algoritma Heuristic Fuzzy Co-clustering, nilai recall terbaik terjadi pada kondisi $\mathrm{Tu}=\mathrm{Tv}=1$ dengan nilai 0,23 . Perbandingan rata-rata recall antara kedua metode tersebut (gambar 5) menunjukkan bahwa nilai recall pada metode HFCR usulan pada masing-masing kondisi Tu=Tv lebih rendah dibandingkan dengan nilai recall metode HFCR.

Secara keseluruhan, hasil pengujian menunjukkan bahwa metode HFCR usulan lebih stabil terhadap kondisi Tu=Tv dibandingkan metode HFCR. Hal ini dapat dilihat dari nilai precission pada tiap kondisi $\mathrm{Tu}=\mathrm{Tv}$ yang cenderung rata dengan selisih nilai yang kecil. Keberagaman nilai pecission dan recall terhadap enam kluster pada tiap metode dipengaruhi oleh pengambilan 600 data cluster dan 200 data berlabel secara acak dengan komposisi jumlah yang tidak merata dari tiap kategori dokumen berita pada 20NewsGroup.

Uji coba dengan parameter kondisi $\mathrm{Tu}=\mathrm{Tv}$ yang berbeda ini menunjukkan bahwa nilai $\mathrm{Tv}$ dan $\mathrm{Tu}$ memberikan pengaruh dalam perhitungan fuzzy dalam menentukan derajat keanggotaan yang digunakan dalam penentuan kelompok kluster.

\section{Kesimpulan}

Berdasarkan hasil pengujian, hasil pengelompokan Algoritma Heuristic Fuzzy Coclustering usulan terbaik dicapai pada kondisi $\mathrm{Tu}=\mathrm{Tv}=\mathrm{dan} 0,01$ dengan nilai precission 0,19 dan 0,16. Algoritma Heuristic Fuzzy Co-clustering usulan memberikan hasil lebih stabil dibandingkan dengan hasil pengelompokan Algoritma Heuristic Fuzzy Co-clustering.

Penelitian selanjutnya dapat difokuskan pada tahap seleksi term untuk menangani masalah dimensi tinggi. Hal ini memberikan pengaruh pada waktu komputasi yang dibutuhkan pada tahap clustering karena semakin banyak jumlah term maka dimensi dari vektor dokumen, sebagai masukan dari metode HFCR yang diusulkan, akan semakin besar.

\section{Referensi}

Cai, Xiaoyan., Li, Wenjie., 2012., Mutually Reinforced Manifold-Ranking Based Relevance Propagation Model for Query-Focused Multi-Document Summarization., Ieee Transactions on Audio, Speech, and Language Processing., VOL. 20,

Yan, Yang., Chen, Lihui., Tjhi, W-C., 2013., Fuzzy semi-supervised co-clustering for Text Document. Fuzzy Sets and Systems., Vol. 215., Pg. $74-89$.

Liu, Chien-Liang., Chang, Tao-Hsing., Li, Hsuan-Hsun., 2013., Clustering documents with labeled and unlabeled documents using fuzzy semi-Kmeans., Fuzzy Sets and Systems., Vol. 221., Pg. 48 64. 
112 Jurnal Buana Informatika, Volume 6, Nomor 2, April 2015: 103-112

Tjhi, William C., Chen, Lihui., 2008., A heuristic-based fuzzy co-clustering algorithm for categorization of high-dimensional data., Fuzzy Sets and Systems., Vol. 159., Pg. 371 - 389.

Chen, Chun-Ling., Tseng, Frank S.C., Liang, Tyne., 2010, Mining fuzzy frequent itemsets for hierarchical document clustering., Information Processing and Management., Vol. 46., Pg. 193211. 